\title{
Examining the Relationship between Psychological Capital and Entrepreneurial Intention: An Exploratory Study
}

\author{
Francoise Contreras ${ }^{1}$, Inge de Dreu ${ }^{2} \&$ Juan C. Espinosa ${ }^{1}$ \\ ${ }^{1}$ School of Management, Universidad del Rosario, Bogotá, Colombia (South America) \\ ${ }^{2}$ International Independent Consultant in Entrepreneurship and Innovation Advisor \\ Correspondence: Francoise Contreras, School of Management, Universidad del Rosario, Bogotá, Colombia \\ (South America). Tel: 57-1-297-0200. E-mail: francoise.contreras@urosario.edu.co
}

Received: December 30, 2016

doi:10.5539/ass.v13n3p80

\author{
Accepted: January 19, 2017 \\ Online Published: February 15, 2017 \\ URL: http://dx.doi.org/10.5539/ass.v13n3p80
}

\begin{abstract}
The aim of this study is determine if Entrepreneurial Intention is related to Psychological Capital in business students. Self-efficacy, Hope, Optimism and Resiliency, which are all dimensions of psychological capital, were assessed with the General Self-Efficacy Scale (GSE), the Hope Scale (HS), the Life Orientation Test Revised (LOT-R) and the Resilience Scale (RS), respectively. The Entrepreneurial Intention was assessed through five statements. According to the results, Entrepreneurial Intention is related to all dimensions of Psychological Capital, mainly with Self-efficacy and Resilience. Psychological Capital as an integrated construct was related to Entrepreneurial Intention as a whole. These findings provide additional evidence about the importance to study Psychological capital as an integrated construct instead of studying its dimensions separately, even more so when studied in relation to Entrepreneurial Intention. In spite of the advances in the knowledge about the individual differences related to entrepreneurial intentions, it is necessary to continue studying this phenomenon, considering that the results are still scarce and inconclusive.
\end{abstract}

Keywords: Entrepreneurial Intention, Psychological Capital, Self-efficacy, Hope, Optimism and Resiliency, Entrepreneurship in Business Students

\section{Introduction}

Entrepreneurship has been object of many academic studies that have included different approaches; nevertheless, it is not sufficiently known what kind of personal factors are related to entrepreneurial intention. It has been associated with social, economic and family conditions, however the psychological characteristics of people who intend to start a new company have not received the same attention. Among these personal features is Psychological Capital, which is defined as a positive psychological state of development, characterized by self-efficacy, hope, optimism and resiliency (Luthans, 2002). Among individual variables that have shown to be related to entrepreneurial behavior are: being a determinate person (Kim-Soon, Ahmad, Saberi, \& Tat, 2013), having a tendency to short-term risk taking (Zhang, Wang, \& Owen, 2015) and having high necessity for achievement (Mat, Maat, \& Mohd, 2015).

It is well known from social psychology, that intention is an accurate predictor of planned behavior. This variable is relevant since it has been found that people with higher entrepreneurial potential usually have more entrepreneurial intentions (Jakopec, Miljković Krečar, \& Sušanj, 2013). There is evidence that entrepreneurial intention depends on the individual's attitude toward entrepreneurship (Moriano, Gorgievski, Laguna, Stephan, \& Zarafshani, 2012), perceived family expectations and beliefs to assume this kind of behavior, perceived behavioral control and perceived ability to execute the intended behavior of entrepreneurship, thus, entrepreneurial behaviour can be predicted accurately, by studying the intention (Krueger, Reilly \& Carsrud. 2000). Likewise, entrepreneurship depends on the external circumstances such as socio-economic variables (Hessels, van Gelderen \& Thurik, 2008; Jolonch \& Ferreira, 2016), for instance, perceived poverty seems to stimulate entrepreneurial intentions (Chen, Shen, Naznin, Wang, \& Wu, 2014). Other authors have found a relation between entrepreneurship and family members who have been entrepreneurs (Ahmed et al., 2010; Singh $\&$ DeNoble, 2003). However, the individual differences, which could have influence on entrepreneurship, remain unclear (Wilson, Marlino, \& Kickul, 2004). 
Although there are other variables studied in relation to entrepreneurial behavior, its findings have been inconsistent. For instance, some studies have been conducted to assess the role of the education in entrepreneurial behavior and they found that this variable had a beneficial effect for nascent entrepreneurs (Rotefoss \& Kolvereid, 2005) and is perceived as necessary and desirable by the students (Guven, 2013). On the contrary, others have demonstrated that entrepreneurship education is not relevant (Ahmed et al., 2010). Without denying the importance of the context and the opportunities mentioned before, this study is addressed to understand, from a psychological approach, if the entrepreneurial intention is related to Psychological Capital (PsyCap) in undergraduate students, who are currently studying their last semesters of business administration.

PsyCap is considered a state-like capacity, which means that it is changeable, potentially malleable and open to development (Luthans, 2002). Psychological Capital is about one's beliefs and the perception of one's abilities (Caza, Bagozzi, Woolley, Levy, \& Barker, 2010; Bandura \& Locke, 2003); it turns out to have a strong effect on performance, even on an operational level (Luthans, Avolio, Walumba, \& Li, 2005).

PsyCap is defined as an individual's positive psychological state of development, which is characterized by four variables viz. self-efficacy, hope, optimism and resiliency (Luthans, 2002). This construct evolved over the years; the most consistent form comprises all of these as State-Like Psychological Resource Capacities (Luthans \& Youssef, 2007). These four dimensions have been studied in organizational settings, and they are providing evidence concerning the influence in diverse work-related performance dimensions.

Self-efficacy in the workplace is defined as "one's conviction (or confidence) about his or her abilities to mobilize motivation, cognitive resources and courses of action needed to successfully execute a specific task within a given context" (Stajkovic \& Luthans, 1998, p. 66). Self-efficacy refers to the confidence in one's abilities to mobilize and move towards a set of goals (Luthans \& Youssef, 2007). It is a form of self evaluation and leads to social comparison (Steyn \& Mynhardt, 2007). Some authors point that this construct turns out to be stable, even though considered a state (Avey, Luthans \& Mhatre, 2008). Self-efficacy is the variable of PsyCap that is more sustained and measured as a state (Bandura, 1997), which means that it is potentially developable (Luthans, Avey, Avolio, Norman, \& Combs, 2006).

The relation between self-efficacy and entrepreneurial behavior has been widely established (Chandler \& Jansen, 1997; Chen, Greene, \& Crick, 1998). This association could be due to the fact that self-efficacy is operationally defined in terms of challenging self-set goals, self-directed initiatives, self-motivation and perseverance, amongst others (Stajkovic \& Luthans, 1998), all of them related to entrepreneurial behavior and intention. Likewise, it may assert that self-efficacy is linked to entrepreneurial intentions (Boissin, Branchet, Emin, \& Herbert, 2009), and it is a significant predictor of entrepreneurial intentions (Moriano et al., 2012; Mat et al., 2015). Zhao, Seibert and Hills (2005), argue that previous experience, risk propensity and formation have an influence on both intentions and self-efficacy as an entrepreneur, as this is about beliefs and perceptions. Foremost, the first step towards creating a company is to believe in one's capabilities to do so. This seems to be more usual in men than in women, in fact, research shows that one of the most important constraints in women entrepreneurs is their tendency to develop less management experience and business skills then men (Heilbrunn, 2004). This might be due to the fact that in business women tend to be subordinate to men, which may cause dynamics that avoids for women create their own companies (Hovorka \& Dietrich, 2011).

On the other hand, the relevance of hope and its impact on performance outcomes have been widely established in the workplace (Luthans \& Youssef, 2007). Hope is defined as a positive motivational state that is based on an interactively derived sense of success (agency and pathways) (Snyder, Irving, \& Anderson, 1991). There are some similarities amongst this concept and the previously cited self-efficacy, although hope involves goal-directed motivations. This manifests in behaviors, of which some could be related to entrepreneurship. However, hope focuses on a different set of mechanisms through which goals are accomplished than self-efficacy; one of these is the sense of agency or internalized control that creates the determination and motivation (willpower) to accomplish one's goals. The other characteristic is the agency-principle, i.e., finding goals and pathways towards those goals (Snyder et al., 2000; Luthans, Norman, Avolio, \& Avey, 2008). Jensen and Luthans (2002) found a relationship between entrepreneurs' hope and their satisfaction with business ownership. More recently it has been observed that hope is an important predictor of entrepreneurial intention (Laguna, 2006).

According to Seligman (1998), optimism is an attributional style that explains positive events through personal, permanent and pervasive causes and negative events through external, temporary, and situation-specific ones. This is confirmed by Jackson, (2009) who also argues that optimism is related to internal attribution to positive events could occur. In some way, like self-efficacy and hope, optimism is used to seek and achieve goals that are 
valuable for the individual (Luthans \& Youssef, 2007), therefore it could also potentially be used to predict leadership behavior and intention (Chemers, Watson, \& May, 2000). In fact, Laguna (2006) found that optimism constitutes an important predictor of entrepreneurial intention. In contrast to the other PsyCap variables, optimism incorporates other personal dimensions, such as cognitive, emotional, and motivational components (Seligman \& Csikszentmihalyi, 2000).

Finally, resiliency is about positive coping and adapting, being able to rebound (Luthans et al., 2008). Luthans (2002) defines resiliency as the capacity to rebound from adversity, conflict, failure, or even positive events that allow people to progress and to increase responsibilities. In this order of ideas, some events could be viewed as opportunities for learning, growing and developing by resilient people or as a threat by those that lack resiliency (Luthans, Youssef, \& Avolio, 2007).

In sum, it seems that having high level of positive psychological resources, such as self-efficacy, optimism, resilience and hope, the entrepreneur may be more able to focus on gains, to persist in the face of adversities, and to successfully move on through the phases of the entrepreneurial process (Gorgievsky \& Laguna, 2008). According to the above exposition, the aim of this study is to determine if entrepreneurial intention is related to variables of Psychological Capital.

\section{Methodology}

\subsection{Participants}

The data for this study came from 109 students of the last year of business studies, who were asked to participate voluntarily in this study. The sample was composed of male and female students ( $32 \%$ and $68 \%$ respectively), with an average of 21.86 years old (1.88 SD).

\subsection{Procedure}

Previous to participation the students were informed and asked for their consent, the participants were to fulfill the questionnaires. The total average time that students spent filling in the questionnaires was 30 minutes. The applications were collectively invited in groups of about 20 people.

\subsection{Measures}

\subsubsection{Views on Self-employment}

To assess entrepreneurial intention, we used a questionnaire composed of 5 statements, designed by Singh and DeNoble (2003). According to these authors, the questionnaire has demonstrated an adequate internal reliability and consistency for all five statements $(0.86)$. Respondents had to indicated if they agree with statement or not (answer Yes/Not).

\subsubsection{General Self-efficacy Scale (GSE)}

This scale is composed of 10 items with 4-point Likert scale. This scale was designed to assess self-efficacy as a general disposition of personality. According to its authors, "General self-efficacy" is the belief in one's competence to cope with a broad range of stressful or challenging demands (Baessler \& Schwarzer, 1996), whereas specific self-efficacy is constrained to a particular task at hand. The GSE was originally created in Germany by Jerusalem y Schwarzer in 1981, used and validated in several researches around the world (Schwarzer, Baessler, Kwiatek, Schröder, \& Zhang, 1997). The GSE had been translated in different languages preserving its high internal consistency (Cronbach's alpha, between 0.79 and 0.93 ) and high convergent and discriminant reliability. In general, the questionnaire has shown good psychometrical properties (Juarez \& Contreras, 2008)

\subsubsection{Hope Scale (HS)}

This scale of eight items with Likert scale of 8 points, was developed and validated by Snyder, et al., (1996). The HS has demonstrated an adequate internal reliability for the overall scale (Cronbach's alpha from 0.90 to 0.95 ) as well as for the subscales (Cronbach's alpha 0.90). The factorial structure and discriminant validity have also shown to be adequate (Feldman \& Snyder, 2000).

\subsubsection{Life Orientation Test Revised (LOT-R)}

This instrument was designed to evaluate dispositional optimism or personal expectations about the good events that could happen in the future. This questionnaire consisted of 10 items, of which 4 were neutral; these were rated to a 5-point scale. It has shown high internal consistency (0.78) and its reliability index is 0.67 (Scheier, Carver \& Bridges, 1994). The LOT-R has been applied and validated in university students, showing a reliability of 0.68 (Ferrando, Chico, \& Tous, 2002). 


\subsubsection{Resilience scale (RS)}

This scale of 25 items and 7-point scale measurement was developed by Wagnild and Young (1993) in order to assess the personal qualities that allow individuals to adapt to new circumstances, which is the capacity to be resilient. RS has demonstrated a high internal consistency (Cronbach's alpha 0.93) (Heileman, Lee, \& Kury, 2003).

\section{Results}

According to the results, the General Self-Efficacy Scale, Hope Scale and Resilience Scale shown adequate reliability values (Cronbach's alpha $.76, .77$ and .78 respectively), all of those values are above the accepted standards (.70). Although the Cronbach's alpha of Life Orientation Test was slightly lower than this reference value (.64), it may assert that it is a consistent measurement as well.

Entrepreneurial Intention was estimated through Views on Self-employment questionnaire. In general, the results point out a high intention among the students involved in the study. The affirmative answer in each item is presented in the Table 1.

Table 1. Affirmative responses to each item in the Views on Self-employment Scale

\begin{tabular}{clc}
\hline Items & Views on self-employment & Yes (\%) \\
\hline Entrepreneur 1 & I intend to become self-employed & $78.90 \%$ \\
Entrepreneur 2 & I have the ability to recognize ideas for self-employment & $85.32 \%$ \\
Entrepreneur 3 & I have the ability to run a business & $92.66 \%$ \\
Entrepreneur 4 & In addition to school/work I would devote my free time to further researching and planning & $72.48 \%$ \\
Entrepreneur 5 & I feel confident enough to quit a secure job in large corporation and start my own business & $75.23 \%$ \\
\hline
\end{tabular}

Psychological Capital dimensions were estimated and re-scaled from 0 to 100 through lineal transformation in order to have the same range in each questionnaire, allowing the comparison between variables. The results of the participants shown high personal resources, getting an average score in the psychological capital scales above 66 points (Table 2).

Table 2. Descriptive Statistics of Psychological Capital ( $\mathrm{n}=109)$

\begin{tabular}{cccc}
\hline Psychological Capital & Minimum & Maximum & M(SD) \\
\hline Self-efficacy & 47 & 100 & $73.61(10.96)$ \\
Optimism & 33 & 96 & $66.12(13.37)$ \\
Hope & 38 & 93 & $73.26(11.40)$ \\
Resilience & 41 & 96 & $72.39(10.04)$ \\
\hline
\end{tabular}

Subsequently, the relation of the Psychological Capital dimension and Entrepreneurial intention were estimated through a point biserial correlation by Pearson correlation approach. The results all dimensions of psychological capital demonstrated to be related to the last three items of entrepreneurial intention (Entrepreneur 3, 4 and 5); in contrast, Entrepreneur 1 and 2 are not related. Regarding the PsyCap dimensions, the results showed that Resilience and Self-efficacy are most related to entrepreneurial intention. Optimism showed to have a lesser relation and mainly with entrepreneur 3 and 5. Finally Hope showed to have a weaker relation to entrepreneurial intention (Only with entrepreneur 5). In Table 3 the values of correlation's coefficients can be observed (Table $3)$.

Table 3. Correlations among Psychological Capital and Entrepreneurial Intentions

\begin{tabular}{lcccc}
\hline & Self-efficacy & Optimism & Hope & Resilience \\
\hline Entrepreneur 1 & $.086(.372)$ & $.118(.222)$ & $.131(.176)$ & $.150(.118)$ \\
Entrepreneur 2 & $.091(.345)$ & $-.024(.801)$ & $.068(.480)$ & $.046(.634)$ \\
Entrepreneur 3 & $.196^{*}(.041)$ & $.281^{* *}(.003)$ & $.159(.100)$ & $.205^{*}(.033)$ \\
Entrepreneur 4 & $.239^{*}(.012)$ & $.121(.209)$ & $.135(.161)$ & $.242^{*}(.011)$ \\
Entrepreneur 5 & $.211^{*}(.028)$ & $.331^{* *}(.000)$ & $.271^{* *}(.004)$ & $.324^{* *}(.001)$ \\
\hline
\end{tabular}

Note: Values are Pearson Correlation (Sig. 2-tailed) 
Finally, the relationship between PsyCap and Entrepreneurial Intention as a whole was estimated through structural equations model. The maximum likelihood estimate model was used (Figure 1).

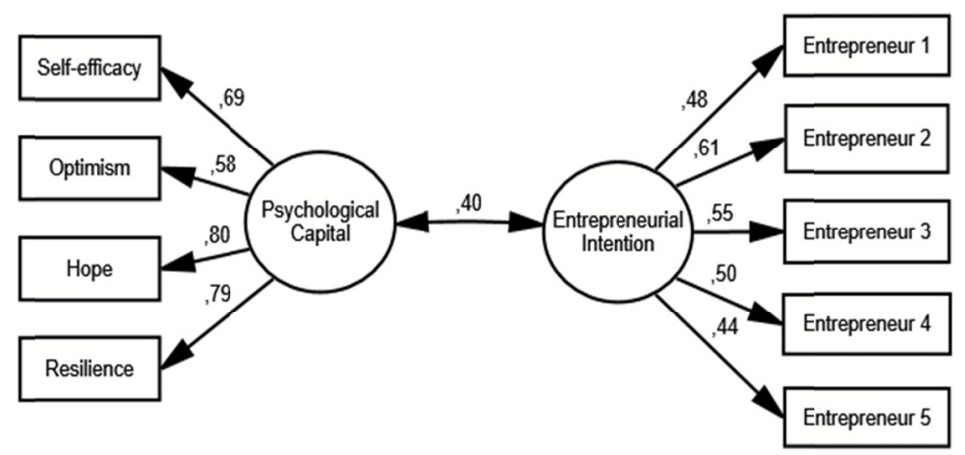

Figure 1. Relationship of Psychological Capital and Entrepreneurial Intentions in business students.

Note: Maximum Likelihood Model. Standardized estimates. Model Adjustment: CMIN/DF= 1.379; GFI = .935; $\mathrm{CFI}=.952$ and $\mathrm{RMSEA}=0.059$

As it can be observed, the fit of the model estimations was highly satisfactory, considering the adjusted values obtained. The Goodness-of-Fit Index (GFI) and the Comparative Fit Index (CFI) were above 90 in both cases, which means that the model has a good adjustment. Moreover, the Chi-square value compared to its associated degrees of freedom (CMIN/DF) is below 3, which is the reference value. Besides, the Root Mean Square Error of Approximation (RMSEA) was below the reference value (0.08) as well. All these fit indexes demonstrated the robustness of the resultant research model in a significant way.

According to the model obtained, it is possible to assert that PsyCap and Entrepreneurial intention, as constructs, can be explained by its components. In the case of PsyCap, Hope and Resilience have more explicative capacity than others. By contrast, Entrepreneurial intentions can be explained in a similar way by its variables. Finally, it is possible to assert that PsyCap and Entrepreneurial Intentions are related, according to the evidence concerning the research objective.

Finally, another important finding obtained by this research is that PsyCap and Entrepreneurial Intention are positive related in a reasonable way, indicating that it could be possible to encourage the entrepreneurial intention in students, through the improvement of their PsyCap, which can be managed at the universities. However, this was an exploratory research and more studies should be developed in order to expand the existent literature. Advances in this scarce field of study, will allow proposing programs of entrepreneurship addressed to business students.

\section{Discussion}

This research provides additional evidence about the individual characteristics that seem to exert influence on entrepreneurial intention, something that remains unclear and should be studied more (Wilson, et al., 2004). According to the results of this study, the questionnaires used were adequate to assess the psychological capital of students, however, in future studies, we suggest to use a more reliable scale to assess optimism. In general, it can be said that participants showed a high entrepreneurial intention and a positive individual attitude toward entrepreneurship, which has been related to the intention as well, according to previous findings (Moriano et al., 2012).

In order to assess the entrepreneurial intention, five items were used. It is interesting to notice that the item that obtained a lower score in this scale, was the item that involves behavior (entrepreneur 4), in other words, it went beyond the intention. This finding shows the difference between entrepreneurial intentions and actions related to entrepreneurship, for instance, those that may involve researching and planning a new business. In spite of the claim that entrepreneurial behavior can be predicted accurately by studying the intention (Krueger, et al., 2000), we suggest that future studies include a measurement of entrepreneurial actions beside entrepreneurial intention, in order to understand these notions separately.

Regarding the relation between PsyCap and entrepreneurial intention, the results of this study allow us to confirm that Resilience and Self-efficacy are most related to the items of entrepreneurial intention. Hope had less relation with the entrepreneurial intention items. Concerning Self-efficacy, these results confirm previous 
findings obtained by several authors (Chandler \& Jansen, 1997; Chen, et al., 1998; Boissin, et al., 2009). On the other hand, the relationship of entrepreneurial intention with both hope and optimism were not high.

Although entrepreneurial intention was assessed with five items, not all of them show the same relation to the PsyCap dimensions. Especially entrepreneur 5: "I feel confident enough to quit a secure job in large corporation and start my own business" was related to all four dimensions of PsyCap. This assertion involves the beliefs in one's own capacities, risk assumption, positive expectations about the future and so on, which are all personal resources or psychological capital. This result is related to entrepreneur 3: "I have the ability to run a business" which shows a relation to PsyCap dimensions except for Hope. If PsyCap could be understood as a source of entrepreneurial potential, then the people with more PsyCap will tend to have more intentions towards entrepreneurship. To this respect, there is evidence as reported for example by Jakopec et al. (2013) who found that people with higher entrepreneurial potential usually have more entrepreneurial intentions. These findings seem to indicate that there are individual characteristics that distinguish between entrepreneurs and non entrepreneurs (Kim-Soon et al., 2013; Zhang et al., 2015). This is something that needs to be studied more in order to provide additional evidence to understand entrepreneurial intention from the individual differences.

Finally, according to the resultant model, both constructs can be explained well by their components. Likewise, this research provides evidence regarding the relation between PsyCap and entrepreneurial intention. Although each dimension of PsyCap has a different relation to entrepreneurial intention, the construct as a whole acquired a moderate predictive capacity. This finding shows correspondence with others studies, which have demonstrated the predictive capacity of PsyCap dimensions but in a separate way. Likewise, entrepreneurial intention could be predicted by self-efficacy (Moriano et al., 2012), hope and optimism (Laguna, 2006). In conclusion, the current results provide evidence to support that psychological resources, such as self-efficacy, optimism, resilience and hope, which together conform the PsyCap, are related to entrepreneurship as was proposed by other authors.

This bond between PsyCap and Entrepreneurial Intention has important implications; one of this is that it is possible to encourage entrepreneurial intention in students through improving their PsyCap, which can be included in the education system, due to the fact that PsyCap is considered a capacity that can be developed as Luthans (2002) asserts. Although this is an exploratory study, the results provide evidence of the relation between PsyCap and entrepreneurial intention.

Finally, it is important considerer that the sample size was a limitation of this study as well as the sex of participants (most of them were women). In future studies we suggest increase the sample size and have a more balanced sample between men and women. Likewise, to have a more diverse sample of participants, including students from different academic backgrounds, due to entrepreneurship is not an exclusive activity of business students.

\section{References}

Ahmed, I., Nawaz, M. M., Ahmad, Z., Shaukat, M. Z., Usman, A., Rehman, W., \& Ahmed, N. (2010). Determinants of students' entrepreneurial career intentions: evidence from business graduates. European Journal of Social Sciences, 15(2), 14-22.

Avey, J. B., Luthans, F., \& Mhatre, K. H. (2008). A call for longitudinal research in positive organizational behavior. Journal of Organizational Behavior, 29, 705-711. https://doi.org/10.1002/job.517

Baessler, J., \& Schwarzer, R. (1996). Evaluación de la autoeficacia: Adaptación española de la escala de autoeficacia general. Ansiedad y Estrés, 2(1), 1-8.

Bandura, A. (1997). Self-efficacy: The exercise of control. New York: Freeman

Bandura, A., \& Locke, E. A. (2003). Negative self-efficacy and goal effects revisited. Journal of Applied Psychology, 88(1) 87-99. https://doi.org/10.1037/0021-9010.88.1.87

Boissin, J., Branchet, B., Emin, S., \& Herbert, J. I. (2009). Students and entrepreneurship: A comparative study of France and the United States. Journal of Small Business and Entrepreneurship, 22(2), 101-122. https://doi.org/10.1080/08276331.2009.10593445

Boyd, N. G., \& Vozikis, G. S. (1994). The influence of self-efficacy on the development of entrepreneurial intentions and actions. Entrepreneurship Theory and Practice, 18, 63-77.

Caza, A., Bagozzi, R. P., Woolley, L., Levy, L., \& Barker, C. (2010). Psychological capital and authentic leadership. Measurement, gender, and cultural extension. Asia-Pacific Journal of Business Administration, 2(1) 53-70. https://doi.org/10.1108/17574321011028972 
Chandler, G. N., \& Jansen, E. (1997). Founder self-efficacy and venture performance: A longitudinal study. Academy of Management Proceedings, 98-102. https://doi.org/10.5465/ambpp.1997.4980945

Chemers, M. M., Watson, C. B., \& May, S. T. (2000). Dispositional affect and leadership effectiveness: A comparison of self-esteem, optimism, and efficacy. Personality and Social Psychology Bulletin, 26, 267-277. https://doi.org/10.1177/0146167200265001

Chen, C. C., Greene, P. G., \& Crick, A. (1998). Does entrepreneurial self-efficacy distinguish entrepreneurs from managers? Journal of Business Venturing, 13, 295-316. https://doi.org/10.1016/s0883-9026(97)00029-3

Chen, S., Shen, Y., Naznin, P., Wang, H., \& Wu, S. (2014). Types of poverty and entrepreneurial intention in Bangladesh. Social Behavior and Personality, 42(5), 857-868. https://doi.org/10.2224/sbp.2014.42.5.857

Feldman, D. B., \& Snyder, C. R. (2000). The State Hope Scale. In J. Maltby, C. A. Lewis, \& A. Hill (Eds.), A handbook of psychological tests (pp. 240-245). Lampeter, Wales: Edwin Mellen Press

Ferrando, P., Chico, E. \& Tous, J. (2002). Propiedades psicométricas del Test de Optimismo. Life Orientation Test. Psichotema, 14, 673-680.

Gird, A., \& Bagraim, J. J. (2008). The theory of planned behaviour as predictor of entrepreneurial intent amongst final-year university students. South African Journal of Psychology, 38(4), 711-724. https://doi.org/10.1177/008124630803800410

Gorgievsky, M., \& Laguna, M. (2008). More Than Money: Gain and Loss Spirals in Entrepreneurship. In J. Moriano, M. Gorgievski \& M. Lukes (Eds.). Teaching Psychology of Entrepreneurship, Perspective from Six European Countries (pp. 159-171) Madrid: UNED

Guven, S. (2013). Determining vocational education undergraduate students' educational needs for entrepreneurship. International Journal of Academic Research, 5(3), 379-383. https://doi.org/10.7813/2075-4124.2013/5-3/b.57

Heilbrunn, S. (2004). Impact of gender on difficulties faced by entrepreneurs. The International Journal of Entrepreneurship and Innovation, 5(3), 159-165. https://doi.org/10.5367/0000000041513420

Hessels, J., Van Gelderen, M., \& Thurik, R. (2008). Entrepreneurial aspirations, motivations, and their drivers. Small Business Economics: An Entrepreneurship Journal, 31, 323-339. https://doi.org/10.1007/s11187-008-9134-x

Hovorka, A. J., \& Dietrich, D. (2011). Entrepreneurship as a gendered process. The International Journal of Entrepreneurship and Innovation, 12(1), 55-65. https://doi.org/10.5367/ijei.2011.0016

Jackson, D. (2009). Editorial: the importance of optimism. Journal of Clinical Nursing, 18, 1377-1378. https://doi.org/10.1111/j.1365-2702.2008.02714.x

Jakopec, A., Miljković Krečar, I., \& Sušanj, Z. (2013). Predictors of entrepreneurial intentions of students of economics. Studia Psychologica, 55(4), 289-297.

Jensen, S. M., \& Luthans, F. (2002). The impact of hope in the entrepreneurial process: Exploratory research findings. Decision Sciences Institute Conference Proceedings, San Diego, CA.

Jerusalem, M., \& Schwarzer, R. (1992). Self-efficacy as a resource factor in stress appraisal processes. In R. Schwarzer (Ed.), Self-efficacy: Thought control of action (pp.195-213). Washington, D.C: Hemisphere. https://doi.org/10.4324/9781315800820

Jolonch, X., \& Ferreira, S. (2016). ¿De qué están hechos nuestros emprendedores? Universidad \& Empresa, 18(30), 179-189. https://doi.org/10.12804/rev.univ.empresa.30.2016.09

Juarez, F., \& Contreras, F. (2008). Psychometric properties of the general self-efficacy.Scale in a colombian sample. International Journal of Psychological Research, 1(2), 6-12

Kim-Soon, N., Ahmad, A. R., Saberi, A. Z. M., \& Tat, H. H. (2013). Discriminate analyses of motivators and obstacles on youth entrepreneurial intention. Asian Social Science, 9(17), 53-57. https://doi.org/10.5539/ass.v9n17p53

Krueger, N., Reilly, M. D., \& Carsrud, A. L. (2000). Competing models of entrepreneurial intentions. Journal of Business Venturing, 15(5), 411-432. http://dx.doi.org/10.1016/S0883-9026(98)00033-0

Laguna, M. (2006). Hope, optimism entrepreneurial intention. Przeglad Psychologiczny 49(4), 419-443.

Luthans, F. (2002). The need for and meaning of positive organizational behavior. Journal of Organizational 
Behavior, 23, 695-706. https://doi.org/10.1002/job.165

Luthans, F., \& Youssef, C. M. (2007). Emerging positive organizational behavior. Journal of Management, 33, 321-349. https://doi.org/ 10.1177/0149206307300814

Luthans, F., Avey, J. B., Avolio, B. J., Norman, S. M., \& Combs, G. M. (2006). Psychological capital development: toward a micro-intervention. Journal of Organizational Behaviour, 27, 387-393. https://doi.org/10.1002/job.373

Luthans, F., Avolio, B. J., Walumba, F. O., \& Li, W. (2005). The psychological capital of Chinese workers: exploring the relationship with performance. Management and Organization Review, 1(2) 249-271. https://doi.org/10.1111/j.1740-8784.2005.00011.x

Luthans, F., Norman, S. M., Avolio, B. J., \& Avey, J. B. (2008). The mediating role of psychological capital in the supportive organizational climate - employee performance relationship. Journal of Organizational Behavior, 29, 219-238. https://doi.org/10.1002/job.507

Luthans, F., Youssef, C. M., \& Avolio, B. J. (2007). Psychological Capital: Developing the human competitive edge. Oxford, UK: Oxford University Press.

Markman, G. D., Balkin, D. B., \& Baron, R. A. (2002). Inventors and new venture formation: the effects of general self-efficacy and regretful thinking. Entrepreneurship Theory and Practice, 149-165. https://doi.org/10.1111/1540-8520.00009

Mat, S. C., Maat, S. M., \& Mohd, N. (2015). A descriptive analysis on entrepreneurial intention among Engineering Technology students. Asian Social Science, 11(24), 286-292. https://doi.org/10.5539/ass.v11n24p286

Moriano, J. A., Gorgievski, M., Laguna, M., Stephan, U., \& Zarafshani, K. (2012). A Cross-Cultural Approach to Understanding Entrepreneurial Intention. Journal of Career Development, 39(2), 162-185. https://doi.org/10.1177/0894845310384481

Neck, C. P., Neck, H. M., Manz, C. C., \& Godwin, J. (1999). I think I can; I think I can: A self leadership perspective toward enhancing entrepreneurial thought patterns, self-efficacy, and performance. Journal of Management Psychology, 14, 477-501. https://doi.org/10.1108/02683949910287912

Pajares, F. (2002). Gender and perceived self-efficacy in self-regulated learning. Theory into Practice, 41(2), 116-125. https://doi.org/10.1207/s15430421tip4102_8

Parker, S. (1998). Enhancing role-breadth self efficacy: The roles of job enrichment and other organizational interventions. Journal of Applied Psychology, 83, 835-852. https://doi.org/10.1037//0021-9010.83.6.835

Peterson, C. (2000). The future of optimism. American Psychologist, 55, 44-55. http://dx.doi.org/10.1037/0003-066X.55.1.44

Rodríguez, M., Pereyra, M. G., Gil, E., Jofré, M., De Bortoli, M., \& Labiano, L. M. (2009). Propiedades psicométricas de la escala de resiliencia versión argentina. Evaluar, 9, 72-82.

Rotefoss, B., \& Kolvereid, L. (2005). Aspiring, nascent and fledging entrepreneurs: an investigation of the business start-up process. Entrepreneurship \& Regional Development, 17, 109-127. https://doi.org/10.1080/08985620500074049

Scheier, M. F., Carver, C. S., \& Bridges, M. W. (1994). Distinguishing optimism from neuroticism (and trait anxiety, self-mastery, and self-esteem): A re-evaluation of the Life Orientation Test. Journal of Personality and Social Psychology, 67, 1063-1078. https://doi.org/10.1037//0022-3514.67.6.1063

Schulman, P. (1999). Applying learned optimism to increase sales productivity. Journal of Personal Selling and Sales Management, 19, 31-37.

Schwarzer, R., Baessler, J., Kwiatek, P., Schröder, K., \& Zhang, J. X. (1997). The assessment of optimistic self-beliefs: Comparison of the German, Spanish, and Chinese versions of the General Self-Efficacy Scale. Applied Psychology: An International Review. 46(1), 69-88. https://doi.org/10.1080/026999497378557

Seligman, M. E. P. (1998). Learned optimism. New York: Pocket Books.

Seligman, M. E. P., \& Csikszentmihalyi, M. (2000). Positive psychology: An introduction. American Psychology, 55, 5-14. https://doi.org/ 10.1007/978-94-017-9088-8_18

Singh, G., \& DeNoble, A. (2003). Views on self-employment and personality: an exploratory study. Journal of Developmental Entrepreneurship, 8(3), 265-281. 
Snyder, C. R., Irving, L., \& Anderson, J. (1991). Hope and Health: Measuring the will and the ways. In C. R. Snyder \& D.R. Forsyth (Eds.), Handbook of social and clinical psychology (pp. 285-305). Elmsford, NY: Pergamon.

Stajkovic, A., \& Luthans, F. (1998). Self-efficacy and work-related performance: A meta-analysis. Psychological Bulletin, 44, 580-590. https://doi.org/10.1037//0033-2909.124.2.240

Steyn, R., \& Mynhardt, J. (2007). Factors that influence the forming of self-evaluation and self-efficacy

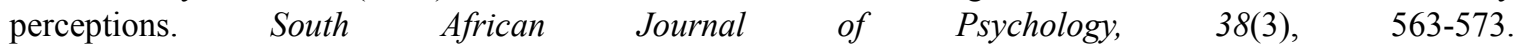
https://doi.org/10.1177/008124630803800310

Wagnild G. M., \& Young H. M. (1993). Development and psychometric evaluation of the Resilience Scale. Journal of Nursing Measurement, 1(2),165-178

Walumbwa, F. O., Luthans, F., Avey, J. B. \& Oke, A. (2009). Authentically leading groups: the mediating role of collective psychological capital and trust. Journal of Organizational Behavior, 32, 4-24. https://doi.org/10.1002/job.653

Wilson, F., Marlino, D., \& Kickul, J. (2004). Our entrepreneurial future: Examining the diverse attitudes and motivations of teens across gender and ethnic identity. Journal of Developmental Entrepreneurship 9(3), 177-197.

Wunderley, L. J., Reddy, W. B., \& Dember, W. N. (1998). Optimism and pessimism in business leaders. Journal of Applied Social Psychology, 28, 751-760. https://doi.org/10.1111/j.1559-1816.1998.tb01729.x

Yang, J. (2013). The theory of planned behavior and prediction of entrepreneurial intention among Chinese undergraduates. Social Behavior and Personality, 41(3), 367-376. https://doi.org/10.2224/sbp.2013.41.3.367

Zhang, P., Wang, D. D., \& Owen, C. L. (2015). A study of entrepreneurial intention of university students. Entrepreneurship Research Journal, 5(1), 61-82. https://doi.org/10.1515/erj-2014-0004

Zhao, H., Seibert, S. E., \& Hills, G. E. (2005). The mediating role of self-efficacy in the development of entrepreneurial intentions. Journal of Applied Psychology, 90(6), 1265-1272. http://dx.doi.org/10.1037/0021-9010.90.6.1265

\section{Copyrights}

Copyright for this article is retained by the author(s), with first publication rights granted to the journal.

This is an open-access article distributed under the terms and conditions of the Creative Commons Attribution license (http://creativecommons.org/licenses/by/4.0/). 